Editorial

\title{
Research on Politics of Disaster Risk Governance: Where Are We Headed?
}

\author{
Dorothea Hilhorst ${ }^{1, *}$, Kees Boersma ${ }^{2}$ and Emmanuel Raju ${ }^{3}$ \\ ${ }^{1}$ Institute of Social Studies, Erasmus University, 2518 AX The Hague, The Netherlands; E-Mail: hilhorst@iss.nl \\ 2 Department of Organization Sciences, Faculty of Social Sciences, Vrije Universiteit Amsterdam, 1081 HV Amsterdam, \\ The Netherlands; E-Mail: f.k.boersma@vu.nl \\ ${ }^{3}$ Copenhagen Centre for Disaster Research, Global Health Section, Department of Public Health, University of Copenhagen, \\ 1014 Copenhagen, Denmark; E-Mail: eraju@sund.ku.dk \\ * Corresponding author
}

Submitted: 13 November 2020 | Published: 10 December 2020

\begin{abstract}
This thematic issue aims at unravelling how the global consensus towards a shift to risk reduction and inclusive disaster governance evolves in everyday governance practices, where roles and responsibilities are evolving and negotiated, permeated by politics of power and legitimacy. It identifies three different dimensions of disaster governance. The first is the formal dimension: the way governance arrangements are designed or meant to work. The second is 'real' governance: the way in which formal governance arrangements manifest and evolve in actual practice. The third is invisible governance: an amalgam of household and neighbourhood-level activities and networks for disaster response that happen outside of the gaze of the formalized governance arrangements. The 21 articles in this issue address the politics of governance based on thorough empirical work, while theoretically contributing to several themes relating to the politics of disaster governance. The outcomes of the thematic issue are: 1 ) The three governance dimensions are useful to reveal what the roles and room for manoeuvre is of different actors, including governments, international community, experts, non-state actors and affected communities; 2) Technical solutions for risk reduction and disaster response crucially rely on socio-technical, political, and administrative systems and processes and hence need to be adjusted to the specific context; and 3) The political nature of disaster governance calls for a deeper understanding to advance accountability to affected populations.
\end{abstract}

\section{Keywords}

disaster governance; formal governance; inclusive disaster governance; invisible governance; politics of disaster governance

\section{Issue}

This editorial is part of the issue "The Politics of Disaster Governance" edited by Dorothea Hilhorst (Erasmus University Rotterdam, The Netherlands), Kees Boersma (Vrije Universiteit Amsterdam, The Netherlands) and Emmanuel Raju (University of Copenhagen, Denmark).

(C) 2020 by the authors; licensee Cogitatio (Lisbon, Portugal). This article is licensed under a Creative Commons Attribution 4.0 International License (CC BY).

\section{Introduction}

Disaster governance is often seen as a technocratic domain, that brings resources and knowledge together to work in prevention, relief and recovery sectors. This view could not be further from the truth, and contrary to its enduring technocratic image, disaster governance is profoundly political. Disaster risks are largely humancreated, and therefore subject to politics. Disasters are the outcome of hazards that are created through human- nature interactions encountering socially produced vulnerabilities. As Olson famously stated, responses to disasters are just as prone to politics, and "within minutes after any major impact, disasters start becoming political" (Olson, 2008, p. 154).

A thematic issue on the politics of disaster governance is especially significant in view of the profound changes that disaster governance has undergone since the turn of the century. Disasters used to be responded to through strict top-down, command-and- 
control response to bring order into the chaos and to return to 'normal.' However, increasing evidence and evolving insights have proven this top-down, bureaucratic governance model to be unrealistic (Dynes, 1994; Neal \& Phillips, 1995) and ineffective, as it did not build on, and often undermined, the response capacities of non-state actors and affected communities (Tierney, Bevc, \& Kuligowski, 2006). The Hyogo Framework for Action of 2005, followed by the Sendai Framework for Disaster Risk Reduction (2015-2030), foresee instead an inclusive governance model for disaster response and disaster risk reduction (DRR; Djalante \& Lassa, 2019; Walker et al., 2010). UN member states have introduced DRR platforms that comprise state actors alongside civil society, science and the private sector. The changing governance model is not only a shift towards more inclusive systems, involving non-state actors and communities in the formal governance of disaster response, but also a recognition of the importance of more proactive attention to risk reduction, including a focus on DRR.

While there is a global consensus towards a model for more inclusive and DRR-oriented forms of disaster governance, the realities are highly diverse. This thematic issue dives into these different realities from the angle of politics of disaster governance. Inclusive governance models are often undermined by path-dependent reliance on top-down approaches (Imperiale \& Vanclay, 2020b), and this is potentially exacerbated by governmental desire for the surveillance and control of, especially, the densely populated and diverse urban areas (Chandler, 2014; Machuki \& McIntyre-Mills, 2017). Where more inclusive models are indeed realised, these are socially embedded in (local) governance arrangements (Melo Zurita, Cook, Harms, \& March, 2015), where they become part of historically grown patterns of power and communication. This is complicated by the sense of crisis that surrounds disasters, that makes disaster response a complex act of navigating between emergency response and routine politics.

Despite the global consensus towards a shift to risk reduction and inclusive disaster governance, we know little of how this evolves in everyday practice where roles and responsibilities are evolving and negotiated, permeated by politics of power and legitimacy. How are different types of actors responding to disasters? Are they working together or in parallel? Are the everyday realities conformant with or divergent from the formal governance arrangements? Further, we need to critically review merits and problems with the shift in disaster governance. Rather than assuming that the new model of governance is a panacea, poignant questions need to be asked, such as: How are disaster governance systems evolving in practice? And what is the evidence that new modes of governance are effective in protecting vulnerable people?

To enable this type of analysis, we identify three different dimensions of disaster governance. The first is the formal dimension: the way governance arrangements are designed or meant to work, including its institutions, roles and responsibilities of different actors, and the interactions between them (Klijn \& Koppenjan, 2015). The second is what Titeca and de Herdt (2011) refer to as 'real' governance: the way in which formal governance arrangements manifest and evolve in practice, influenced by interests, power differentials, organizational culture and other factors that enable or constrain the composition and operation of formal governance arrangements. 'Real' governance also comprises the informalities surrounding bribery, collusion, and political corruption that are often apparent in disaster response (Ansell \& Gash, 2008; Veron, Williams, Corbridge, \& Srivastava, 2006). The third is what we tentatively label as invisible governance: an amalgam of household and neighbourhood level activities and networks for disaster response that happen outside of the gaze of the formalized governance arrangements but underlie and affect such arrangements and practices nonetheless (see for example Price, Albrecht, Colona, Denney, \& Kimari, 2016). This can be, for example, because these networks and activities are not 'seen' (Bankoff \& Hilhorst, 2009), prefer to remain invisible because of lack of trust in authorities, or because they involve unrecognized non-state authority structures, such as local gangs that may effectively play dominant roles in disaster response.

The idea that underpins this thematic issue is that to advance our understanding of multi-dimensional and contextual disaster governance, we must take an empirical approach to understand its working in different aspects and settings. All 21 articles in this issue comprise empirical work, while theoretically contributing to several themes relating to the politics of disaster governance.

\section{Themes and Articles}

The issue starts with a set of articles that question how real the current trend is towards DRR-focused and inclusive governance. Starting with the uneasy realization that DRR-oriented disaster policies are developed amidst continuing politics and practices resulting in disaster risk creation, Pereira Covarrubias and Raju (2020) open the issue with an article on the intensifying production of disaster risks in Latin America, where 'neo-extractivism' brings about an ecological-political pattern of intensive natural resource exploitation. Imperiale and Vanclay (2020a), on the other hand, pose the question as to what extent inclusive governance models have actually taken ground. In their analysis of responses to the April 6, 2009 earthquake in L'Aquila, Italy, they show how a command-andcontrol approach that centralised knowledge, technologies and responsibilities, stifled the capacities of localities to reduce disaster risks and facilitated a disaster capitalism at all levels of society. Raising a similar point, Fuentealba, Verrest, and Gupta (2020) consider in their article the scenario of urban disaster, and analyse theoretically and empirically how DRR politics in urban con- 
texts may (re)produce urban inequalities and spatial injustice. Finally, Wanner's (2020) article brings evidence that the extent to which countries shift to DRR-oriented policies only partly correlates with the frequency and impact of disasters, and otherwise depends on political drivers related to, for instance, questions of voice, accountability and general development policy.

The theme on how broader legislation and politics (may) impact disaster governance is elaborated by Miriam Cullen's (2020) article that explores how international law can-or cannot-be relevant for increasing disaster-related displacement, largely in the context of climate change. With a special focus on a Swedish case study, Per Becker (2020), focusing at the micro level, addresses the complications inherent to flood risk governance that should encompass the river catchment, whereas this rarely coincides with the normal administrative levels and units of governance. Anholt's (2020) article sets out to analyse how the discursive buzzword of 'resilience' shapes the governance of refugee programmes in the Middle East, and on what assumptions policies and programmes for resilience are built. The last article on the theme of the importance of wider politics is by Stuart Gordon (2020) and directs our attention to the important topics of how 'risk management' of banks in relation to counter-terrorist financing legislation, designed to counter flows of money to terrorists, is reproduced within the governance and regulatory structures of humanitarian institutions where it distorts patterns of emergency assistance coverage.

A next set of articles analyses roles, strategies and practices of non-state actors in disaster governance. This starts with Rubin and Bækkeskov (2020) who zoom in on the role of experts. Illustrating the importance of discursive strategies, they show how experts drove the securitisation of public policy in a case study of the 2009 flu pandemic in Denmark and Sweden. Meriläinen, Mäkinen, and Solitander (2020) discuss the role of nonprofit organizations in disaster governance, with a scenario involving the American Red Cross in the US and Haiti, analysing the politics of the entangled relations between non-profit organizations, states, and disasteraffected people. Desportes and Hilhorst (2020) analyse the room for manoeuvre of non-state actors in settings dominated by authoritarian and controlling governments. Drawing from case studies in the low-intensity conflict areas of Ethiopia, Myanmar and Zimbabwe, they analyse the different strategies that non-state actors develop to navigate disaster politics, trying to uphold their mandate and gain access to the communities they need to serve.

Continuing on disaster response in a conflict-setting, and zooming in on the role of disaster-affected communities, Jessica Field's (2020) case study on Kashmir opens up the profoundly relational character of disaster governance, in the vertical (local-centre) politics of border security and conflict, as well as in rarely researched horizontal relations between neighbouring communities.
Melis and Apthorpe (2020) further unpack and theorize what constitutes the 'local' in the new buzzword of humanitarian 'localisation.' Based on studies of three post-conflict settings, namely Nepal, Sierra Leone and Haiti, the article coins the idea of the multi-local where the local is much more than a 'locale,' and may be seen as a site for local-national and intra-national strife and a source of legitimation of different actors involved in disaster governance. Duda, Kelman, and Glick (2020) further elaborate on the role of local communities. Focusing on the strength of Arctic communities in handling the 2020 Covid-19 pandemic, they raise the question if disaster governance should accord more importance to local and informal arrangements for disaster governance. In a concurring article, Yang and Wu (2020) analyse how an ageing rural community in Taiwan used its social capital to successfully mobilize its citizens for disaster preparedness. Nimesh Dhungana (2020), finally, drawing on the case of post-earthquake Nepal, provides an analysis of what it means and takes to be 'doing accountability' and hold power holders to account during disaster response. The civil society-driven initiative for social accountability that the article is about was challenged by what turned out to be the 'real' governance of donordriven humanitarian action and unclear response systems in the post-disaster context.

A final theme addressed in the issue concerns the politics of disaster response data and technologies. Femke Mulder (2020) starts this discussion with an article that focuses on knowledge in humanitarian governance and shows how knowledge-sharing can be blocked by institutional politics manifested through (self-)censorship, contested framings and priorities, deliberate ICT black-outs, and the withholding (or not collecting) of mission-critical information. Clark and Albris (2020) provide a discussion on the governance of data in disaster situations and review, on the basis of a political realist perspective, if data challenges during crises can be governed in the same ways that data is governed in periods of normalcy. Shifting to early warning and early action, and using two case studies in Indonesia and Sri Lanka, the article of Sakalasuriya et al. (2020) seeks to understand the workings of a tsunami early warning system and the social, cultural and political dynamics of its operationalisation. This is further elaborated in the final article by Bierens, Boersma, and van den Homberg (2020) that analyses how the use of forecasting and forecast-based financing, turning early warnings into early action, is marred by questions of legitimacy, accountability and ownership. The last article by van den Homberg, Gevaert, and Georgiadou (2020) reviews how the increasing reliance on digital technologies and data impacts the practises of the Red Cross Red Crescent movement in the Philippines, and concludes that remote data analytics have the potential to strengthen disaster governance capacity while they also affect the roles, relations and conduct of actors involved in disaster governance. 


\section{Major Themes for Further Research}

The collection of articles presented here highlight three key issues on disaster governance that need deeper analysis in the future.

1. Unpacking and understanding the different dimensions of disaster governance in different contexts and scenarios. Our three-dimensional model of formal, real and invisible disaster governance may be universal, but how this plays out and what the roles and room for manoeuvre is of different actors, including governments, international community, experts, non-state actors and affected communities continues to be a vast and highly diverse terrain of theoretical and empirical work.

2. A major lesson from the articles in this thematic issue is that technical solutions for DRR and disaster response crucially rely on socio-technical, political, and administrative systems and processes and hence need to be adjusted to the specific context (e.g., Ingram, 2013; Jasanoff, 2012; Sarewitz, 2004). The development and application of technology is highly political because power relations and technology are mutually constitutive. Power shapes technology and vice versa, for example when designs of early warning platforms are not accessible to marginalized people (Williams \& Edge, 1996). Technological innovation is important for disaster response and risk reduction, but there is no technical fix for a social problem. Technology thus needs to be studied in its wider socio, cultural and political context.

3. The political nature of disaster governance calls for a deeper understanding to advance accountability to affected populations. Research can focus on grasping the impact of old and new models of governance on affected populations and support people's voices, their participation in invited and uninvited spaces of accountability, and the advocacy efforts of vulnerable communities in the face of disaster politics.

\section{Acknowledgments}

The issue has been made possible as part of a research grant of the Netherlands Organisation for Scientific Research (NWO), 453/ 14/013.

\section{Conflict of Interests}

The authors declare no conflict of interests.

\section{References}

Anholt, R. (2020). Resilience in practice: Responding to the refugee crisis in Turkey, Jordan, and Lebanon. Politics and Governance, 8(4), 294-305.
Ansell, C., \& Gash, A. (2008). Collaborative governance in theory and practice. Journal of Public Administration Research and Theory, 18(4), 543-571.

Bankoff, G., \& Hilhorst, D. (2009). The politics of risk in the Philippines: Comparing state and NGO perceptions of disaster management. Disasters, 33(4), 686-704.

Becker, P. (2020). The problem of fit in flood risk governance: Regulative, normative, and culturalcognitive deliberations. Politics and Governance, 8(4), 281-293.

Bierens, S., Boersma, K., \& van den Homberg, M. J. C. (2020). The legitimacy, accountability, and ownership of an impact-based forecasting model in disaster governance. Politics and Governance, 8(4), 445-455.

Chandler, D. (2014). Resilience: The governance of complexity. London: Routledge.

Clark, N., \& Albris, K. (2020). In the interest(s) of many: Governing data in crises. Politics and Governance, $8(4), 421-431$.

Cullen, M. (2020). Disaster, displacement and international law: Legal protections in the context of a changing climate. Politics and Governance, 8(4), 270-280.

Desportes, I., \& Hilhorst, D. (2020). Disaster governance in conflict-affected authoritarian contexts: The cases of Ethiopia, Myanmar, and Zimbabwe. Politics and Governance, 8(4), 343-354.

Dhungana, N. (2020). Doing civil society-driven social accountability in a disaster context: Evidence from post-earthquake Nepal. Politics and Governance, 8(4), 395-406.

Djalante, R., \& Lassa, S. (2019). Governing complexities and its implication on the Sendai Framework for Disaster Risk Reduction priority 2 on governance. Progress in Disaster Science, 2. https://doi.org/ 10.1016/j.pdisas.2019.100010

Duda, P. I., Kelman, I., \& Glick, N. (2020). Informal disaster governance. Politics and Governance, 8(4), 375-385.

Dynes, R. R. (1994). Community emergency planning: False assumptions and inappropriate analogies. International Journal of Mass Emergencies and Disasters, 12(2), 141-158.

Field, J. (2020). Caught between paper plans and Kashmir politics: Disaster governance in Ladakh, India. Politics and Governance, 8(4), 355-365.

Fuentealba, R., Verrest, H., \& Gupta, J. (2020). Planning for exclusion: The politics of urban disaster governance. Politics and Governance, 8(4), 244-255.

Gordon, S. (2020). Regulating humanitarian governance: Humanitarianism and the 'risk society'. Politics and Governance, 8(4), 306-318.

Imperiale, A. J., \& Vanclay, F. (2020a). Barriers to enhancing disaster risk reduction and community resilience: Evidence from the L'Aquila disaster. Politics and Governance, 8(4), 232-243.

Imperiale, A. J., \& Vanclay, F. (2020b). Top-down reconstruction and the failure to "build back better" 
resilient communities after disaster: Lessons from the 2009 L'Aquila Italy earthquake. Disaster Prevention and Management, 29(4), 541-555. https://doi. org/10.1108/DPM-11-2019-0336

Ingram, H. (2013). No universal remedies: Design for contexts. Water International, 38(1), 6-11.

Jasanoff, S. (2012). Science and public reason. New York, NY: Routledge.

Klijn, E. H., \& Koppenjan, J. (2015). Governance networks in the public sector. London: Routledge.

Machuki, S., \& Mclntyre-Mills, J. (2017). The role of participatory and inclusive governance in sustainable urban development of Nairobi, Kenya: A participatory approach. In J. McIntyre-Mills, N. Romm, \& Y. Corcoran-Nantes (Eds.), Balancing individualism and collectivism: Social and environmental justice (pp. 239-257). Cham: Springer.

Melis, S., \& Apthorpe, R. (2020). The politics of the multilocal in disaster governance. Politics and Governance, 8(4), 366-374.

Melo Zurita, M. D. L., Cook, B., Harms, L., \& March, A. (2015). Towards new disaster governance: Subsidiarity as a critical tool. Environmental Policy and Governance, 25(6), 386-398.

Meriläinen, E., Mäkinen, J., \& Solitander, N. (2020). Blurred responsibilities of disaster governance: The American Red Cross in the US and Haiti. Politics and Governance, 8(4), 331-342.

Mulder, F. (2020). Governing the humanitarian knowledge commons. Politics and Governance, 8(4), 407-420.

Neal, D. M., \& Phillips, B. D. (1995). Effective emergency management: Reconsidering the bureaucratic approach. Disasters, 19(4), 327-337.

Olson, R. S. (2008). Toward a politics of disaster: Losses, values, agendas, and blame. In R. A. Boin (Ed.), Crisis Management (pp. 154-170). London: Sage.

Pereira Covarrubias, A., \& Raju, E. (2020). The politics of disaster risk governance and neo-extractivism in Latin America. Politics and Governance, 8(4), 220-231.

Price, M., Albrecht, P., Colona, F., Denney, L., \& Kimari, W. (2016). Hustling for security: Managing plural security in Nairobi's poor urban settlements. The Hague and Nairobi: Clingendael and Rift Valley Institute.
Rubin, O., \& Bækkeskov, E. (2020). Expert-led securitization: The case of the 2009 pandemic in Denmark and Sweden. Politics and Governance, 8(4), 319-330.

Sakalasuriya, M., Haigh, R., Hettige, S., Amaratunga, D., Basnayake, S., \& Rahayu, H. (2020). Governance, institutions and people within the interface of a tsunami early warning system. Politics and Governance, 8(4), 432-444.

Sarewitz, D. (2004). How science makes environmental controversies worse. Environmental Science \& Policy, 7(5), 385-403.

Tierney, K. J., Bevc, C., \& Kuligowski, E. (2006). Metaphor matters: Disaster myths, media frames, and their consequences in Hurricane Katrina. The Annals of the American Academy of Political and Social Science, 604(1), 57-81.

Titeca, K., \& de Herdt, T. (2011). Real governance beyond the failed state: Negotiating education in the Democratic Republic of Congo. African Affairs, 110(439), 213-231.

van den Homberg, M. J. C., Gevaert, C. M., \& Georgiadou, Y. (2020). The changing face of accountability in humanitarianism: Using artificial intelligence for anticipatory action. Politics and Governance, 8(4), 456-467.

Veron, R., Williams, G., Corbridge, S., \& Srivastava, M. (2006). Decentralized corruption or corrupt decentralization? Community monitoring of povertyalleviation schemes in eastern India. World Development, 34(11), 1922-1941.

Walker, B., Pearson, L., Harris, M., Maler, K. G., Li, C. Z., Biggs, R., \& Baynes, T. (2010). Incorporating resilience in the assessment of inclusive wealth: an example from South East Australia. Environmental and Resource Economics, 45(2), 183-202.

Wanner, M. S. T. (2020). Drivers of change in national disaster governance under the Hyogo Framework for Action. Politics and Governance, 8(4), 256-269.

Williams, R., \& Edge, D. (1996). The social shaping of technology. Research Policy, 25(6), 865-899.

Yang, A. H., \& Wu, J. S.-H. (2020). Building a disasterresilient community in Taiwan: A social capital analysis of the Meizhou experience. Politics and Governance, 8(4), 386-394.

\section{About the Authors}

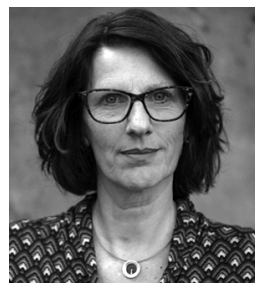

Dorothea Hilhorst is a Professor of humanitarian studies at the International Institute for Social Studies (ISS) of Erasmus University in The Hague. Her focus is on aid-society relations: studying how aid is embedded in the context. She has a special interest in the intersections of humanitarianism with development, peacebuilding and gender-relations. Currently, her main research programme concerns cases where 'disasters meets conflict,' that studies disaster governance in high-conflict, low-conflict and post-conflict societies. For more details: https://dorotheahilhorst.nl 


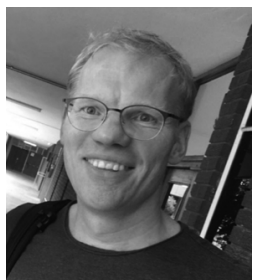

Kees Boersma is an Associate Professor and Research Manager at the Vrije Universiteit Amsterdam, in the Organization Sciences Department. His research interest is in crisis management, disaster studies, and innovation management. He is Co-Founder of the Crisis Resilience Academy of the Institute for Societal Resilience. His current projects include: EU Horizon 2020 project "LINKS: Strengthening links between technologies and society for European disaster resilience," (PI) and the EU Horizon 2020 Covid-19 project "HERoS: Health Emergency Response in Interconnected Systems" (WP Leader).

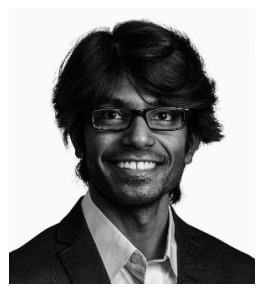

Emmanuel Raju is an Associate Professor at the Global Health Section, University of Copenhagen, and currently directs the Copenhagen Centre for Disaster Research. He is the Co-Editor of the Disaster Prevention and Management journal. He is also an Extraordinary Associate Professor at the African Centre for Disaster Studies, South Africa. His research interests include disaster risk reduction, governance, climate change adaptation and development. 